\title{
The Meaning of the Biblical Citations in the Expositio of Berthold of Moosburg
}

\author{
Paul D. Hellmeier OP \\ Ludwig-Maximilians-Universität München
}

Although for Berthold of Moosburg, as for any medieval Christian thinker, Scripture functions as a crucial source of doctrine, no one has yet looked in detail at the biblical citations in Berthold's Expositio. Perhaps this is because Berthold quotes other works and authors much more frequently and in more detail than the Bible. Nevertheless, the passages where Berthold quotes the Bible or alludes to it should not be overlooked. ${ }^{2}$

About a third of these quotations can already be found in the texts that Berthold takes over from other authors. These are a total of 14 authors, of whom Honorius Augustodunensis (with 23 citations), Dionysius the Areopagite (13 citations), and Thomas of York (9 citations) are the most important. In about two-thirds of the cases, however, Berthold himself inserts these biblical quotations into his commentary. Berthold's scriptural quotations are always short passages, usually only single verses or parts of verses. These quotations vary in their character, ranging from exact citations to somewhat modified citations, references, and allusions. The vast majority, however, are exact or slightly changed citations. In more than a third of these cases, Berthold shows through different formulations that he is consciously quoting the Bible. These quotations appear as single quotations or in small groups. In the latter case, they form a kind of network of mutual relationships - a technique found in many medieval biblical commentaries, e.g. in those of Albert the Great. ${ }^{3}$ Often, these clusters of quotations appear in texts that Berthold has taken over from other

1 I am grateful to Innocent Smith op for his critical remarks.

2 For detailed documentation of the following statistics, see the Appendix.

3 For overviews of medieval exegesis and biblical hermeneutics see the classic studies of B. Smalley, The Study of the Bible in the Middle Ages (Oxford: Blackwell, $1984^{3}$ ) and H. de Lubac, Exégèse médiévale. Les quatre sens de l'Écriture, 4 vols (Paris: Aubier, 1959-1964). For more recent studies, see La Bibbia nel Medio Evo, eds G. Cremascoli, C. Leonardi (Bologna: EDB, 1996); G. Dahan, L'exégèse chrétienne de la Bible en Occident médiéval. XII ${ }^{e}-X I V^{e}$ siècle 
authors. These clusters tend to indicate that particularly important issues are being addressed, such as the Trinity, the resurrected body, beatitude, the primordial causes, etc. Berthold rarely offers interpretations of these biblical citations, but rather uses them to interpret the philosophical context in which they appear, or to contextualize the philosophical content of his commentary in a Christian frame.

These quotations are frequently found in volumes one, four, five, and eight of the critical edition. If we add up all the quotations indicated by the Index auctoritatum of this edition, we get the number 159. In addition, there are at least 38 other quotations and allusions overlooked by the editors, ${ }^{4}$ which add up to 197 biblical references. However, since the Index auctoritatum contains several mistakes, the real number of biblical references is $194 .{ }^{5}$ In other words, nineteen percent of Berthold's biblical citations have been overlooked. Here is the list of the omitted biblical citations, arranged according to the volume of the critical edition. This list shows that Berthold quotes some passages of the Bible particularly often, for example Romans 11:36 or passages from the Book of Wisdom.

$\begin{array}{ll}\text { Volume 1:6 }^{6} & \\ \text { Sapientia 9:15 } & \text { p. } 7,1.5^{6} \\ \text { Liber Proverbiorum 25:27 } & \text { p. 7, 1. 68-69 } \\ \text { Psalmus 49(50):1 } & \text { p. 12, l. 243-244 } \\ \text { Ad Timotheum I 6:15 } & \text { p. 16, 1.349-350 } \\ \text { Proverbia 9:1 } & \text { p. 18, 1. } 420 \\ \text { Daniel 3:54 } & \text { p. 18, 1. } 434\end{array}$

(Paris: Cerf, 1999); id., Lire la Bible au Moyen Âge. Essais d'herméneutique médiévale (Genève: Librairie Droz, 2009).

4 By "overlooked citations" I mean citations, allusions, or references which are not mentioned in the footnotes of the text or in the Index auctoritatum.

5 For further details on these passages, see the Appendix. In a few cases, the index of the critical edition gives incorrect information about biblical citations present in Berthold's text. In one case the index refers to a biblical passage which does not exist in Berthold's text. Three times the editors list several biblical parallels in the apparatus corresponding to only one citation in Berthold's text. These parallels also appear in the indices, but without any indication that they are merely parallels. On rare occasions, Berthold quotes the same biblical passage twice on the same page of the critical text, which is mentioned by the editors in the footnotes, but is not indicated in the index. Also on rare occasions, the editors omitted biblical passages from the index which were indicated in the footnotes of the text.

6 Berthold of Moosburg, Expositio super Elementationem theologicam Procli. Prologus. Propositiones 1-13, eds M.R. Pagnoni-Sturlese, L. Sturlese (Hamburg: Meiner, 1984). 
$\begin{array}{ll}\text { Psalmus 144:3 } & \text { p. } 18,1.435 \\ \text { Psalmus 144(145):13 } & \text { p. } 16,1.36 \circ-361 \\ \text { Ad Timotheum I 6:16 } & \text { p. } 18,1.432 \\ \text { Daniel 3:54 } & \text { p. } 18,1.434 \\ \text { Canticum Cant. 2:9 } & \text { p. } 34,1.944-945\end{array}$

Volume $2:{ }^{7}$

Evang. sec. Ioannem 1:3 p. 196, l. 201-202

Volume $3:^{8}$

Psalmus $94(95): 3 \quad$ p. $173,1.98-99$

Volume $4:^{9}$

Psalmus 95(96):4 p. 208, 1. 171

Volume $5::^{10}$

Ad Romanos 11:36 p. $84,1.36$

Ad Romanos 9:5 p. 134, l. 321

Sapientia 11:21 p. $168,1.79-80$

Psalmus $35(36): 9 \quad$ p. $179,1.191$

Ad Corinthios I 15:28 p. 179, l. 194

Evang. sec. Ioannem 1:16 p. 191, l. $55^{-p}$ p. 192, l. $5^{6}$

Ad Romanos 11:36 p. 211, 1.164

Volume 6:11

Ad Romanos 11:36 p. 9, l. 178; p. 40, l. 88; p. 136, 1.132

Evang. sec. Lucam 1:79 p. $70,1.357$

Ad Ephesios 3:15 p. 136, 1.137

Epist. Ioannis I 1:5 p. 171, 1.69

$7 \quad$ Berthold of Moosburg, Expositio super Elementationem theologicam Procli. Propositiones 14-34, eds L. Sturlese, M.R. Pagnoni-Sturlese, B. Mojsisch (Hamburg: Meiner, 1986).

8 Berthold of Moosburg, Expositio super Elementationem theologicam Procli. Propositiones 35-65, ed. A. Sannino (Hamburg: Meiner, 2001).

9 Berthold of Moosburg, Expositio super Elementationem theologicam Procli. Propositiones 66-107, ed. I. Zavattero (Hamburg: Meiner, 2003).

10 Berthold of Moosburg, Expositio super Elementationem theologicam Procli. Propositiones 108-135, ed. F. Retucci (Hamburg: Meiner, 2011).

11 Berthold of Moosburg, Expositio super Elementationem theologicam Procli. Propositiones 136-159, ed. F. Retucci (Hamburg: Meiner, 2007). 
Sapientia 11:21

p. $199,1.311$

Volume $7:^{12}$

Ad Timotheum I 6:16

p. $20,1.151-15^{2}$

Ad Romanos 11:36

p. $196,1.259-260$

Volume 8:13

Cf. Evang. sec. Matth. 17:1 $\quad$ p. 25, l. 36o-361; p. 185, l. 131-132

Cf. Sapientia 11:21

p. $77,1.37$

Cf. Ad Corinthios I 15:54

p. 13 o, 1. 244

Psalmus 17(18):12

p. $188,1.225^{-226}$

Psalmus 94(95):3

p. $188,1.226-227$

Isaias 12:4

p. $190,1.22$

Ad Romanos 8:21

p. $249,1.87-88$

Ad Corinthios II 4:18

p. $249,1.93-94$

One could object that the number 194 is not large (e.g. compared to the hundreds of citations of Aristotle or Augustine), and that these places are almost always single verses or even only partial verses that seem to get lost in the sea of the Expositio. However, the mere number is not decisive in this case, since, among all his other sources, the Bible has an authoritative status as revealed truth. This truth is unquestionable for him, as Berthold confirms on the last pages of his Expositio with a quotation from Honorius Augustodunensis:

Discipulus: De causarum omnium incommutabili perseverantia in ipsa divina substantia, quod est verbum Dei patris, in quo et per quod facta sunt et subsistunt, nullo modo dubitarim: Illud siquidem et divina Scriptura et sanctorum Patrum traditio incunctanter asserit. ${ }^{14}$

The prominent position that Berthold assigns to the Bible is also made clear by the fact that the Expositio begins with a citation from Rom 1:19-20:

12 Berthold of Moosburg, Expositio super Elementationem theologicam Procli. Propositiones 160-183, eds U.R. Jeck, I.J. Tautz (Hamburg: Meiner, 2003).

13 Berthold of Moosburg, Expositio super Elementationem theologicam Procli. Propositiones 184-211, ed. L. Sturlese (Hamburg: Meiner, 2014).

14 Berthold of Moosburg, Expositio, 211D, p. 262, l. 152-155 ("Disciple: In no way do I doubt the unchanging constancy of all causes in the divine substance itself, which is the word of the Father in and through which they are and exist. This both divine Scripture and the tradition of the fathers declare without hesitation."). 
INVISIBILIA ENIM DEI [Vulg. “ipsius"] A CREATURA MUNDI PER EA,
QUAE FACTA SUNT, INTELLECTA CONSPICIUNTUR, Ad Rom., 1 cap.

Summus divinalis sapientiae theologus Paulus secretorum Dei conscius utpote in tertium caelum raptus loquens de mundanae philosophiae sapientibus, postquam dixerat: 'Quod notum est Dei, manifestum est illis: Deus enim illis revelavit', subiungit: 'Invisibilia Dei' etc. ${ }^{15}$

Since the final volume of the critical edition shows a substantial accumulation of quotations from St. Paul (there are fourteen quotations, six of which can be found in the last two propositions), one can perhaps even speak of a Pauline frame that encloses the entire Expositio. This can be seen in the following table of all biblical citations in the Expositio.

\begin{tabular}{|c|c|c|c|c|c|c|c|c|c|}
\hline Volume & 1 & 2 & 3 & 4 & 5 & 6 & 7 & 8 & Total \\
\hline Propositiones & $1-13$ & $14-34$ & $35^{-65}$ & 66-107 & $108-135$ & $13^{6}-159$ & $16 o-183$ & $184-211$ & \\
\hline Pentateuch & 5 & 1 & - & - & 4 & 1 & - & 4 & 15 \\
\hline Wisdom Books & 47 & 2 & 1 & 1 & 11 & 10 & 1 & 5 & 78 \\
\hline Wisdom & $(29)$ & $(-)$ & (1) & (1) & (5) & $(-)$ & (1) & $(2)$ & (39) \\
\hline Psalms & $(8)$ & $(2)$ & $(-)$ & $(-)$ & $(6)$ & $(10)$ & $(-)$ & $(2)$ & $(28)$ \\
\hline Prophets & 5 & - & - & - & - & 1 & 1 & 1 & $\begin{array}{c}8 \\
\text { O.T. } 101\end{array}$ \\
\hline Gospel & 1 & 1 & - & - & 6 & 2 & - & 6 & 16 \\
\hline St. Paul & 18 & 2 & - & 2 & 14 & 13 & 3 & 14 & 66 \\
\hline Cath. Epistles & 2 & 2 & $\begin{array}{l}- \\
-\end{array}$ & - & 1 & 6 & - & - & $\begin{array}{c}11 \\
\text { N.T. } 93\end{array}$ \\
\hline Total & 78 & 8 & 1 & 3 & 36 & 33 & 5 & 30 & 194 \\
\hline
\end{tabular}

15 Berthold of Moosburg, Expositio, Prol. 1, p. 5, 1. 2-8 ("The invisible realities of God are perceived as recognized from the creation of the world through that which is created. Rom, ch. 1.

The greatest theologian of divinely inspired wisdom, Paul, knowing the secrets of God, having been raptured into the third heaven, thus spoke of the wise men of worldly philosophy. Before he had said: 'What is known of God is manifest to them, for God has revealed it to them.' Then he adds 'The invisible realities', etc."). 
Let us now take a closer look at the table indicating how the biblical quotations are distributed among the individual volumes of the critical edition and from which books and groups of books of Holy Scripture they come. What does this show? And what questions arise in view of this distribution?

First of all, there is a very uneven distribution of quotations: as already mentioned, most are found in volumes one, five, six, and eight. In addition, 73 of the 78 quotations of the first volume can be found in the Prologus, with only two in the Expositio tituli and three in Propositions 1-13.

A partial explanation for this distribution can be given for volumes five, six, and eight. In Berthold's view, the movement of ascent to the One begins in Proposition 108 (the opening proposition of volume five of the critical edition). Berthold explicitly mentions this turning point. ${ }^{16}$ The remainder of the commentary concerns the gods or henads, the separate intelligences, and souls, and their relationship to the One and Good. However, Berthold interprets the henads as primordial causes and the One as the Trinitarian God. These two interpretations are very often supported and further explained by quotations from the Bible (see below). Berthold then discusses the major topics of contemplation and eschatology in volume eight (Propositions 184-211). These topics are also extensively treated in Holy Scripture and Christian theology, which can explain why Berthold repeatedly refers to the Bible here.

The table also illustrates the distribution of quotations from the Old and New Testament. We see here that quotations from the Old Testament slightly predominate, which is mainly due to the frequent quotations from the Wisdom Books. This frequency may be due to the fact that statements from the Wisdom Books are particularly suitable for philosophical representations. Incidentally, Meister Eckhart showed a strong interest in this group of writings for the same reason. Within the Wisdom Books, the Psalms are most prominent in the Expositio. After all, Berthold prayed the Psalms daily and probably knew them by heart from the time of his novitiate.

16 Berthold of Moosburg, Expositio, 108, p. 3, 1. 7-11: Postquam superius descensum est a causis seu unitatibus primordialibus et amethectis ad causata participantia per derivationem proprietatum, investigationem et ipsorum ordinum et distinctionem et ad se invicem conexionem, nunc auctor in isto elemento incipit ostendere reductionem quorundam causatorum in suas prime causas per duplicem participationem dicens: OMNE etc. 
Among the quotations from the New Testament, those from the Pauline epistles form the largest group. ${ }^{17}$ I have already suggested above that St. Paul plays an important role for Berthold. ${ }^{18}$ This central role is related to the fact that the tradition regarded St. Paul as the master of Dionysius - an identification emphasized by several statements of Pseudo-Dionysius himself. ${ }^{19}$ However, in Berthold's view, Proclus had received fundamental impulses from Dionysius! This connection explains why for Berthold St. Paul is the summus divinalis sapientiae theologus and a secretorum Dei conscius.

\section{3}

\section{More General Questions}

In view of the 194 biblical citations in the Expositio more general questions also arise: What kind of citations are these and how does Berthold use them? Does he use them as authorities, or as evidence, or are they just decorative accessories? What is their purpose? Why do they even appear in a commentary on a philosophical work? For comparison: the Bible is never quoted in Albert's commentary on the Liber de causis (at least not explicitly). Do Berthold's biblical citations serve only to protect him against possible accusations of heterodoxy? Or do they have a deeper meaning for the whole Expositio?

This last question leads to another one, that is, the significance of Christian theology for the Expositio. In previous research, opinions differ on this issue. Willehad Paul Eckert said that Berthold wrote the Expositio as a theologian. ${ }^{20}$ According to Kurt Flasch, Berthold did not want to become a "theologian of revelation"; instead he stuck to the "immanent philosophical character of his interpretations". ${ }^{21}$ According to Loris Sturlese, the theme of grace plays a very subordinate role in the Expositio, and "there is no mention of sacraments, church, revelation, good works and faith". ${ }^{22}$ In the eyes of Fiorella Retucci,

17 According to the medieval view I count Hebrews among the Pauline epistles.

18 See p. 33 of this contribution.

19 B.R. Suchla, Dionysius Areopagita. Leben -Werk - Wirkung (Freiburg: Herder, 2008), p. 15-17. Dionysius ps.-Areopagita, De divinis nominibus, ed. Ph. Chevallier, Dionysiaca, vol. 1 (Bruges: Desclée de Brouwer, 1937), c. 2, 649D-652A, p. 117-118; c. 3, 681A-B, p. 130; c. 7,865 B-C, p. $381-382$.

20 W.P. Eckert, Berthold von Moosburg O.P. und sein Kommentar zur Elementatio Theologica des Proklos, PhD diss. (Ludwig-Maximilians-Universität München, 1956), p. 51; id., "Berthold von Moosburg O.P. Ein Vertreter der Einheitsmetaphysik im Spätmittelalter", in Philosophisches Jahrbuch 65(1957), p. 131.

21 K. Flasch, "Einleitung", in Berthold of Moosburg, Expositio, vol. 1, p. xiv; p. xxxii.

22 L. Sturlese, Homo divinus. Philosophische Projekte in Deutschland zwischen Meister Eckhart und Heinrich Seuse (Stuttgart: Kohlhammer 2007), p. 146. 
Berthold interpreted "the relationship between revealed religion and rational knowledge not in the sense of an integration of pagan wisdom into the Judeo-Christian concept of revelation, but rather as an equal coexistence."23 For Ezequiel Ludueña, on the other hand, Berthold wanted to "offer a Christian interpretation of Proclean thought". ${ }^{24}$ However, this strong assessment is immediately weakened by the statement that Berthold wanted to establish a dialogue between Dionysius and Proclus. ${ }^{25}$ Furthermore, for Ludueña, Berthold had tried to show a philosophical agreement of Christian, pagan, and Arabic thinking. Philosophy serves as a means of dialogue between Islam, Christianity, and pagan philosophy. ${ }^{26}$

\section{Five Thematic Groups}

But let us now return to the question of the meaning of the biblical citations within the Expositio. A more detailed analysis of the citations is necessary to answer this. First of all, such an examination shows that almost all citations can be assigned to one of five thematic groups that often overlap, especially in the Prologus. The first group deals with the absolute position of the One and Good and its relationship to creation. The second group deals with the primordial causes, the third with the Trinity, the fourth with contemplation, and the fifth with eschatology and the Resurrection. Berthold presents all five themes in the Prologus, and thus uses many biblical quotations in the Prologus (73 in 35 pages) except in the case of eschatology and the Resurrection. ${ }^{27}$ The following are some examples for each thematic group, first from the Prologus and then from the commentary itself.

23 F. Retucci, "Einleitung", in Berthold of Moosburg, Expositio, vol. 5, p. xvii.

24 E. Ludueña, La recepción de Eriúgena en Bertoldo de Moosburg. Un aporte sobre la Escuela de Colonia, (Saarbrücken: Publicia, 2013), p. 15; see also p. 94.

25 Ludueña, La recepción de Eriúgena, p. 15.

26 E. Ludueña, "Eriúgena en el siglo XIV. Su presencia en la Expositio de Bertoldo de Moosburg", in Scintilla 10(2013), p. 131.

27 For comparison, some examples of how often Berthold quotes other important authors (or works) in the Prologus: Dionysius ps.-Areopagita: 51; Augustine: 16; Proclus: 15; Albertus Magnus: 14; Asclepius: 12; Cicero: 4; Aristotle: 3; Dietrich of Freiberg: 2; Thomas Aquinas: 1; Averroes : o. 


\subsection{The Absolute Position of the First One and Good and Its Relationship to Creation}

In Prologus 4 there is a passage that is typical for Berthold in its combination of quotations from the Psalms and from St. Paul. It reads:

De istis dis, super quod Deus 'magnus, dominus et rex magnus' < Ps 94:3>, 'princeps Deus et superdeus supersubstantialiter unus Deus', 'nimis exaltatus' <Ps 96:9> est, utpote 'Deus deorum dominus' <Ps 49:1>, sic dicit Dionysius ex verbis Apostoli <I Cor. 8:5-6>: 'Etenim si sunt di sive in caelo sive in terra, sicut quidem sunt di et domini multi, sed nobis quidem unus Deus Pater, ex quo omnia et nos in ipso, et unus dominus Iesus Christus, per quem omnia et nos per ipsum.' ${ }^{28}$

Here, through quotations from the Psalms and from Dionysius, the absolute superiority of the one God over the many gods is emphasized. Since Berthold understands these gods to be the primordial causes, the subsequent reference to St. Paul takes on a new meaning, since in the original Pauline context it is about the gods of the pagan religion and not about primordial causes. On the other hand, the quotation of St. Paul, who here is explicitly considered to be the source of Dionysius, also contributes further information: the one God who brings forth and sustains everything is the Father and the Lord Jesus Christ.

In Prologus 9, Berthold first emphasizes the absolute superiority of God over the primordial causes with the same quotations from Psalms 94(95) and 96(97). Because of this superiority, God's work and domain are also superior to those of the primordial causes. According to Berthold's interpretation of Proclus, the primordial causes rule over only a portion of the universe. Thus their domains fall short of the perfection of God's works. Berthold then describes the work of God as an eternal kingdom, using several verses from the Psalms (144[145]:13 and 148:6). ${ }^{29}$ These biblical verses appear to function

28 Berthold of Moosburg, Expositio, Prol. 4, p. 12, l. 218-223 ("About those gods, over which 'the great God, the Lord and great king' <Ps. 94(95):3>, the 'first God and super-god, the supersubstantial one God' 'is far exalted' $<$ Ps. 96(97):9> because he is 'God, the Lord of gods' $<$ Ps. 49(50):1>, Dionysius says the following using the words of the Apostle $<$ I Cor. 8:5-6>: "Indeed, even though there are gods in heaven and on earth, to be sure, many "gods" and many "lords", yet for us there is one God, the Father, from whom all things are and toward whom we return, and one Lord, Jesus Christ, through whom all things are and through whom we exist."').

29 Berthold of Moosburg, Expositio, Prol. 9, p. 16, 1. 353-362: Cum igitur primordiales causae sint super totum universum principalissimae, ipsae sunt reges et domini et di, super quas et earum regna et dominia est Deus magnus, dominus et rex magnus super omnes deos $<$ Ps. 94(95):3>, super quos etiam nimis exaltatus est $<$ Ps. 96(97):9>. Unde et operi suo non 
as authoritative affirmations of the preceding argument, which is based on a statement of Proclus. The fluent and natural transition from philosophical principles to biblical quotations suggests a deep synthesis of philosophical and biblical reasoning.

A good example of Berthold using the Bible as an authority can be found in the commentary on Proposition 133. Here Berthold proves the opinion that in nature all things take the position that is best for them with the statement Dei perfecta sunt opera. This could be read simply as a philosophical argument. However, the formulation comes from Deuteronomy 32:4. ${ }^{30}$ Berthold's argument is thus ultimately based on a statement that is taken directly from the Bible.

\subsection{The Primordial Causes}

Since the primordial causes are also part of creation, they have already been dealt with in the first thematic group, insofar as they are inferior to God. In the second group, the primordial causes are considered in themselves. In this regard, too, Berthold applies statements from Scripture to the primordial causes. He does this almost exclusively by interpreting biblical images, especially from the Psalms, as metaphors and symbols for the primordial causes. One of the many examples of this can be found in Prologus 9, where Berthold writes:

Dicuntur autem primordiales causae 'caeli' <Ps. 148:4> [...], id est summi Dei domus, qui inhabitat caliginem et 'lucem inaccessibilem' $<$ I Tim. 6:16>, et 'posuit tenebras latibulum suum' <Ps. 17(18):12>; quae omnia significant ipsas primordiales causas. ${ }^{31}$

With such identifications Berthold apparently wants to show the concordance of biblical and Platonic wisdom. In this way new meanings are opened up for the biblical statements. However, Berthold also interprets the Platonic

est simile in omnibus regnis deorum, qui licet regnent et principentur in regnis suis secundum Proclum De malorum existentia, tamen quia regna sua sunt partiales universitates, partes scilicet totius universitatis, ideo deficiunt a perfectione eius, quae simpliciter omnia summi Dei opera est complexa, quae est regnum omnium saeculorum <Ps. 144:13>; cuius gloriam etiam ipsi di dicent, dicentes ipsum esse opus altissimi Dei, qui 'statuit ipsum in aeternum et in saeculum saeculi' $<$ Ps. 148:6>.

30 Berthold of Moosburg, Expositio, 133H, p. 211, l. 175-p. 212, l. 183.

31 Berthold of Moosburg, Expositio, Prol. 9, p. 14, 1.309-313 ("The primordial causes are called 'heavens' $<$ Ps. 148:4> [...], i.e. house of the highest God, who dwells in darkness and in 'inaccessible light' <I Tim. 6:16>, and who 'made darkness his hiding place' <Ps. 17(18):12>; which all means the primordial causes."). 
understanding of the world in the light of revelation. This second consequence can also be seen in the continuation of the passage just discussed. Referring to Honorius, Berthold interprets the primordial causes as the water above which the Spirit hovered in the beginning (Genesis 1:2), which leads Berthold to explicate the creation of the primordial causes as the common work of the three divine Persons. ${ }^{32}$

On several occasions Berthold also makes use of Scripture by analogously applying to the higher causes statements that originally referred to the believer or to divine wisdom. He states in the Prologus that the primordial causes are built up in the Holy Spirit into a dwelling place of God (Ephesians 2:21-22). ${ }^{33}$ In the commentary on Proposition 143, Berthold applies the words "the mirror of eternal light" and "image of his goodness" (Wisdom 7:26) to all higher causes. ${ }^{34}$ In doing so, he does not reinterpret the meaning of Scripture, but he does extend its scope - as was usual for medieval authors. ${ }^{35}$

\subsection{Trinity}

The Trinity is mentioned very early in the Prologus, since for Berthold it constitutes the first and most important component of the Invisibilia Dei (intransitively understood), which are explored in the Expositio. In Prologus 3, Berthold uses the three-part verse I Timothy 1:17 containing the keyword "invisible" and its Trinitarian interpretation by the Glossa to open his discussion of the Trinity. Then he makes several very clear dogmatic statements by contradicting the error of the Arians with quotations from Augustine and rejecting a false understanding of Colossians 1:15 (qui est imago Dei invisibilis). The Son is homousion, id est coessentialis Patri. ${ }^{36}$ Later, Berthold talks again about the Son when,

32 Berthold of Moosburg, Expositio, Prol. 9, p. 14, l. 313-p. 15, l. 320: Sunt et 'aquae', quae super caelos sunt, secundum expositionem Theodori in Clave, ubi exponit illud Gen. 1: 'Spiritus domini ferebatur super aquas' id est 'super conditas causas cognitionis excellentia supereminet'. Ipse enim Deus deorum, scilicet Deus Pater, 'dixit', id est Filium genuit, in quo ista divinissima 'facta sunt'; ipse 'mandavit' istis divinissimis, scilicet primordialibus causis, 'et creata sunt' omnia in ipsis, id est per ipsas, per Spiritum sanctum, qui eas in effectus suos dividit et multiplicat.

33 Berthold of Moosburg, Expositio, Prol. 11, p. 19, l. 473-p. 20, l. 476.

34 Berthold of Moosburg, Expositio, 143L, p. 70, l. 351-352. Berthold can apply those words to the higher causes since these causes can be understood as existing within the eternal Wisdom or Word of God. I am grateful to Evan King for making this suggestion.

35 See note 3 , above.

36 Berthold of Moosburg, Expositio, Prol. 3, p. 7, 1. 77-p. 8, 1. 91: Circa primum sciendum, quod li INVISIBILIA DEI potest accipi dupliciter, vel intransitive, vel transitive. Primo modo, ut sit sensus: invisibilia Dei, id est quae sunt Deus, iuxta illud I Ad Tim. 1 cap.: 'Regi saeculorum immortali' (Glossa: 'immutabili'), 'invisibili' (Glossa: 'incomprehensibili'), 'regi saeculorum' (Glossa: 'Trinitati'). Augustinus libro De videndo Deo cap. 2 tractans verba Ambrosii sic 
following Hebrews 11:3, he states that we know by faith that the world was created by the Word of God. ${ }^{37}$

In Prologus 19, Berthold identifies the One and Good itself, which he presents here as the Beautiful itself, with the Trinity. In his introduction to the first volume of the critical edition Kurt Flasch observes the following: "Berthold pretended that the 'One' of Proclus was the Christian Trinity; without transition he also called the prime pulchrum the superbenedicta Trinitas." ${ }^{38}$ Now it is undoubtedly true that such identification was unthinkable for Proclus. But Berthold by no means makes this identification without transition; rather, he prepares it by the keyword fontana pulchritudo and then interprets that identification further using three quotations of the Bible. All three quotations deal with splendour and brightness and illustrate the admirable, even frightening beauty of the Son and the Holy Spirit that emerge from the paternal origin. ${ }^{39}$

It is well known that in the Expositio, Berthold twice explores the question of whether the existence of the Trinity can be recognized by the philosophers' arguments (Propositions 40 and 131). Previous research has focused exclusively on Berthold's affirmation of this question, but not on the role of the Trinity in his work. ${ }^{40}$ I will not analyse this role here either, as it is not the subject of this contribution. But I would like to make two notes for now. First, the Expositio is interspersed with shorter remarks or longer elaborations on the Trinity. Secondly, these statements on the Trinity are very often introduced,

dicit: 'Deus natura est invisibilis'. Et infra: 'Arianorum procul dubio error astruitur, si Patris natura invisibilis, Fili vero visibilis creditur, utriusque unam pariterque invisibilem asseruit esse naturam adiungens et Spiritum sanctum?. Et infra: 'Invisibilis igitur Deus natura, non tantum Pater, sed et ipsa Trinitas unus Deus.' Haec Augustinus. Non solus Pater, sicut quidam exponunt illud Apostoli Ad Col. 1 cap., ubi loquitur de Filio, 'qui est imago Dei invisibilis' homousion, id est coessentialis Patri, et sic est invisibilis sicut et Pater.

Berthold of Moosburg, Expositio, Prol. 3, p. 8, 1. 115-116: Ad Hebr. 11: 'Fide intelligimus aptata esse saecula Verbo Dei, ut ex invisibilibus visibilia fierent'.

38 Flasch, "Einleitung”, p. xxi: "er tat so, als sei das 'Eine' des Proklos die christliche Trinität; übergangslos nannte er das 'prime pulchrum' auch 'superbenedicta Trinitas' [...]."

39 Berthold of Moosburg, Expositio, Prol. 19, p. 29, 1. 776-788: Aut secundum causam, puta primum: et enim pulchrum illud propter traditam ab ipso iuxta cuiuslibet proprietatem pulchritudinem, cum sit causa consonantiae et claritatis universorum et ad seipsum omnia vocans et tota in totis congregans ad idem. Et haec est fontana pulchritudo omne pulchrum in semetipso excedenter praehabens, ut dictum est, et hoc est prime pulchrum, superbenedicta Trinitas, ut de ea intelligatur illud: 'Pulchritudinem candoris eius admirabitur oculus, et super imbrem expavescit cor' $<$ Eccl. 43:20 $>$. Ecce candor lucis aeternae $<$ cf. Sap. 7:26 $>$ et splendor gloriae paternae et figura substantiae eius <cf. Hebr. 1:3>, id est character substantialis et imago bonitatis illius; pulchritudinem, inquam, superpulcherrimam et candoris, scilicet Filii, et lucis paternae admirabitur oculus contemplantis, et super imbrem Spiritus sancti expavescit cor virorom gloriosorum deditum in virtute pulchritudinis studium habentium $[\ldots]$.

The exception to this is Ludueña, La recepción de Eriúgena, p. 146-154. 
illustrated, or supported by biblical quotations. A typical example of this is the quotation from Romans 11:36 (ex ipso et per ipsum et in ipso sunt omnia) in the commentary on Proposition 126, which initiates a highly speculative explanation of the relationship between Trinitas and Unum..$^{41}$ In the same proposition, a quotation from Genesis 1:2 introduces an analysis of the creative work of the Father, the Son, and the Holy Spirit. ${ }^{42}$ Elsewhere, in Proposition 151, referring the paternal quality to God, which for Proclus belongs to the highest henad, Berthold cites three passages from the letters of St. Paul, and he even quotes extensively from the Nicene Creed. ${ }^{43}$

\subsection{Contemplation}

I now turn to the last two topics, namely the theory of contemplation and the doctrines of eschatology and the Resurrection. Berthold repeatedly quotes the Bible in the Prologus when he addresses the ground and principle of the highest human contemplation. In this context he quotes Genesis 1:27 three times: Fecit Deus hominem ad imaginem et similitudinem suam. ${ }^{44}$ Being made in the image of God makes man capax Dei and enables him to turn to God and to receive from God the beautiful ideas (pulchritudines) that are free from space and time. ${ }^{45}$ Berthold defines the image of God in man more precisely as the unum of man, which is brighter than the simple intellect, and describes the way in which the unum is imprinted on man with the image of the seal mentioned in Psalm 4:7. Then, with an allusion to I Corinthians 13:12, he says that in the present, God is imperfectly seen by this image, but in the future he will be seen face to face. ${ }^{46}$ This is the first reference in the commentary to the eschatological expectation that is understood in personal categories, since the beatific vision is not conceived as a vision of cosmological structures, but as a vision of God's face. Thus the eschatological perfection of man is presented here as a personal encounter with God face to face. This personal concept coincides with two other passages in the Prologus where Berthold, referring to other verses of the Bible, articulates the goal of contemplation as the vision

\footnotetext{
41 Berthold of Moosburg, Expositio, 126A-B, p. 154, l. 10-p. 157, l. 97.

42 Berthold of Moosburg, Expositio, 126B, p. 156, l. 77-p. 157, l. 91.

43 Berthold of Moosburg, Expositio, 151A, p. 133, l. 33-40.

44 Berthold of Moosburg, Expositio, Prol. 12, p. 21, l. 516-517; Prol. 18, p. 27, l. 730-731; Prol. 19, p. 32, l. $877-878$.

45 Berthold of Moosburg, Expositio, Prol. 18, p. 27, 1. 729-734: Sic ergo homo subnexus Deo vero et indicibili uni per suum unum, hoc est per divinam similitudinem - uno enim suo, quod est imago ipsius Dei, qua homo est capax Dei et connexus Deo, habet similitudinem Dei, immo est similitudo Dei et deus participatione -, est accipiens secundum Trismegistum pulchritudines non immersas mundo, hoc est continuo et tempori.

46 Berthold of Moosburg, Expositio, Prol. 19, p. 31, l. 858-p. 32, l. 878.
} 
of the Son or Word, ${ }^{47}$ who, of course, also includes the noetic structures of the cosmos. Like his master Dionysius, Berthold also refers to Philippians 4:7 when describing the ecstatic union of man with God:Pax Dei, quae exsuperat omnem intellectum..$^{48}$ The penultimate page of the Prologus, where Berthold discusses the soul's contemplative ascent to God, reads like a Psalm commentary. In fact, Berthold draws on the commentary of Peter Lombard on Psalm 41(42) (Sicut cervus)..$^{49}$

\subsection{Eschatology and the Resurrection}

The subject of the Resurrection appears only once in the Prologus, when Berthold includes the blessed with their glorified bodies among the invisibilia $D e i$ (transitively understood). ${ }^{50}$ Even though this reference to the Resurrection is singular in the Prologus, nevertheless it should make us sit up and take notice. Resurrection is not a theme found in Proclus, and does not belong to providentia naturalis but to providentia voluntaria. Kurt Flasch's assessment thus appears highly problematic: "In the course of his investigation Berthold recorded the immanent philosophical character of the theories of Proclus' and his own interpretation with the formula in ordine providentiae naturalis." ${ }^{11}$ The accuracy of this assessment seems even more doubtful when we consider how often Berthold deals with the glorified bodies of the resurrected in the actual commentary on the Elementatio theologica.

Berthold does this prominently and with explicit reference to providentia voluntaria in the commentary on Proposition 129. He first gives extensive quotations from Dietrich of Freiberg's arguments about the status of glorified bodies, "the bosom of Abraham" (Luke 16:22), purgatory, and hell. These are the places where the souls who have left their bodies will accept their bodies again in the future Resurrection. ${ }^{52}$ But this is not all that Berthold has to say about the Resurrection. He wants to explain, using the example of man, what Proclus means in Proposition 129 about the top-down process of deification. According to Proclus, this process starts with the henads and, through mediation of the intellects and souls, extends to bodies. Analogous to this, for Berthold, drawing on Dionysius and Proclus, the deification of man begins with the union of the "one in us" with the divine One. Because of the connection of the "one in us"

\footnotetext{
47 Berthold of Moosburg, Expositio, Prol. 19, p. 29, l. 785-786; Prol. 21, p. 34, l. 968-973.

48 Berthold of Moosburg, Expositio, Prol. 17, p. 26, l. 683-684.

49 Berthold of Moosburg, Expositio, Prol. 20, p. 33, l. 939-p. 34, l. 967.

$50 \quad$ Berthold of Moosburg, Expositio, Prol. 6, p. 13, 1. 279-28o.

51 Flasch, "Einleitung", p. xxxii: "Mit der Formel 'in ordine providentiae naturalis' hielt Berthold im Laufe seiner Untersuchung den immanent-philosophischen Charakter der Theorien des Proklos und seiner, Bertholds, Auslegung fest."

Berthold of Moosburg, Expositio, 129A, p. 176, l. 94-p. 177, l. 13 o.
} 
with the human intellect, which in turn is connected with the soul, deification finally reaches the body. ${ }^{53}$ Berthold thus expresses the result:

Et sic participatio divinitatis transit per omnia media usque ad deificationem corporis. Et sic, ut dicit Bernardus, totus homo perget in Deum et deinceps adhaerens ei unus cum eo spiritus erit <I Cor. 6:16>. 'Quomodo stilla aquae modica multo infusa vino deficere a se tota videtur, dum et saporem vini induit et colorem', 'sic omnem tunc in sanctis (scilicet quando quasi ebrii ab ubertate domus Domini <Ps. 35(36):9> quodammodo obliti sui ipsorum fuerint) humanam affectionem quodam ineffabili modo necesse erit a semet ipsa liquescere atque in Dei penitus transfundi voluntatem. Alioquin, quomodo erit Deus omnia in omnibus <I Cor. 15: 28>, si in homine de homine quidquam supererit? Manebit quidem substantia, sed in alia forma, alia gloria aliaque potentia.. Haec Bernardus. Sic enim implebitur homo 'in omnem plenitudinem Dei' $<$ Eph. 3:19>. ${ }^{54}$

Eugenio Massa comments on this important passage:

A faint sense of the Bible is enough to recognize an echo of the eschatology of St. Paul: ut sit Deus omnia in omnibus. [...] In other words, up to the first part of section B, the Expositio filters Neoplatonism into a Christian ethical and soteriological context. Patristic tradition illuminates the watermark that appears for Berthold on the page of Proclus: the breath of a living and experiential theory breathes in an archaeological park. Even for the Dominican philosopher, in the garden of the archetypes burns the pure love of St. Bernard: et sic, ut dicit Bernhardus, 'totus homo perget in Deum ...' $[\ldots] .^{55}$

53 Berthold of Moosburg, Expositio, 129B, p. 178, l. 155-p. 179, l. 186.

54 Berthold of Moosburg, Expositio, 129B, p. 179, 1. 187-197 ("And thus the participation in deity reaches through all levels down to the deification of the body. And thus, as Bernard says, the whole human being advances to God and finally, attached to him, becomes one spirit with him <I Cor 6:16>. 'As a small drop of water, when poured into much wine, seems to pass away completely when it takes on the taste and colour of the wine', 'so in the case of the saints every human aspiration is necessarily inexpressibly liquefied by itself and poured entirely into the will of God (that is, when drunk of the riches of the Lord's house $<$ Ps. 35(36):9> they have in some way forgotten themselves). For how else could God be all in all $<$ I Cor. 15:28>, if there were anything left in man of man? Of course the substance remains, but in a different form, in another glory and in another power.' This is what Bernard says. For in this way man is filled with all the fullness of God <Eph. 3:19>."). E. Massa, "La deificazione nel commento di Bertoldo di Moosburg a Proclo, Elementatio theologica, 129. Edizione del testo e prime analisi”, in R. Lievens, E. Van Mingroot, 
Another place where the Expositio expresses a connection between the unitive knowledge of God and the Resurrection can be found in the commentary on Proposition 185. Berthold presents here a quotation from On the Divine Names. According to Dionysius, having become immortal we will receive a Christ-like form and will always be with the Lord (I Thessalonians 4:17). We will see him like the apostles at the Transfiguration on the mountain and participate in his radiance in an incomprehensible union. According to Luke 20:56 we will then be sons of God and sons of the Resurrection. ${ }^{56}$

A very important section for the Expositio is the commentary on Proposition 202, in which Berthold gives a detailed commentary on the subject of contemplation. Quite naturally, he bases his statements on the Christian distinction contemplatio in via - contemplatio in patria. At the end of his discussion, Berthold says that the human soul does not always recognize reality because its essentia intellectualis, that is, its intellectus agens, is not always united to the soul as its form. But then Berthold explains:

[...] tamen dono Dei aliquando etiam in hac mortali vita, non iam suo intellectuali, sed etiam suo uniali seu uno altitudine contemplationis elevantur in visionem non solum deorum, quos posuit prime Deus suum latibulum $<$ Ps. 17(18):12>, sed etiam eius, qui est Deus magnus dominus et rex magnus super omnes deos $<$ Ps. 95(96):3>. Sed post hanc vitam bene meritae animae Dei gratia (scilicet lumine gloriae) habebunt sibi proprios intellectus formaliter unitos, et sic complebitur eorum visio

W. Verbeke (eds), Pascua Mediaevalia. Studies voor Prof. Dr.J.M. De Smet (Leuven: Leuven University Press, 1983), p. 550: "Un fioco senso della Bibbia basta a ravvisarvi una reminiscenza della escatologia paolina: 'ut sit Deus omnia in omnibus'. [...] In altre parole, fino alla prima parte della sezione B, l'Expositio filtra il neoplatonismo in un contesto etico e soteriologico cristiano. La tradizione patristica illumina la filigrana che traspare a Bertoldo dalla pagina di Proclo: il soffio d'una teoria viva ed esperimentale alita in un parco archeologico. Anche per il filosofo domenicano, nel giardino degli architipi arde l'amor puro di s. Bernardo: 'et sic, ut dicit Bernhardus, totus homo perget in Deum ...' [...]."

56 Berthold of Moosburg, Expositio, 185 H, p. 25, 1. 356-365: Hae enim secundum Dionysium, immo nos toti, 1 cap. De divinis nominibus, 'tunc, quando incorruptibiles et immortals erimus, christiformem et beatissimum consequemur finem, semper cum Domino secundum Eloquium erimus visibili ipsius Dei apparitione in castissimis contemplationibus adimpleti, manifestissimis circa nos splendoribus refulgente, sicut circa discipulos in illa divinissima transformatione; intelligibili autem luminis datione ipsius impassibili et immateriali mente participantes et super mentem unitione in ignotis et beatis immissionibus superclarorum radiorum in diviniore imitatione supercaelestium mentium. Nam aequales erimus angelis, ut veritas dicit Eloquiorum, et filii Dei resurrectionis filii existentes.' 
beata, inquantum videbunt Deum deorum dominum facie ad faciem $<$ I Cor. 13:12> specula in aeterna. ${ }^{57}$

Not only does Berthold here quote Scripture three times, but he also speaks quite naturally of God's gift, of grace and merit, and - what for Dietrich of Freiberg would be horribile dictu - of the lumen gloriae. ${ }^{58}$

Finally, it should be mentioned that Berthold's statements at the end of the Expositio on the resurrected body are not the typical expressions of the Church's orthodox faith, even though he repeatedly quotes St. Paul. Following Honorius (who draws on Eriugena), Berthold understands the resurrected body as a purely spiritual substance. ${ }^{59}$

Berthold uses biblical citations for five crucial topics for the Expositio: first, the absolute position of the first One and Good (prime unum et prime bonum) and its relationship to creation; second, the primordial causes; third, the Trinity; fourth, contemplation; and, fifth, eschatology and the Resurrection. Among these themes, the last two are particularly important, since they deal with

57 Berthold of Moosburg, Expositio, 202F, p. 188, l. 223-231 ("Nevertheless, through a gift from God they are sometimes also raised in this life, not only with their intellectual principle, but also with their unifying principle, or with their one, through the height of contemplation, not only to the vision of the gods, which the first God has made his hiding place $<$ Ps. 17(18):12>, but also to the vision of him who is God, the great Lord and the great King over all gods $<$ Ps. 95(96):3 $>$. But after this life the meritorious souls by the grace of God (namely by the light of glory) will possess their own intellects as formally united to them, and so their blissful vision will be completed insofar as they will see the God of gods and the Lord face to face <I Cor. 13:12>, [the souls] being mirrors for all eternity."). I translate intellectuale with "intellectual principle" and uniale with "unifying principle", for it seems that for Berthold the uniale is much more than just a power or a faculty. He understands it as the core of man's being. My translation of the difficult phrase specula in aeterna interprets specula as a nominative plural of speculum. Specula would then be in apposition to animae. In aeterna I interpret as a temporal determination. Another possible translation is: "from the eternal height". According to this translation we would assume a "poetical" word order, in which the preposition in and the adjective aeterna refer to the ablative singular specula (watchtower or height).

$5^{8}$ Berthold's notion of lumen gloriae, however, is not clear. For Dietrich's rejection of the concept of lumen gloriae see Dietrich of Freiberg, De visione beatifica, ed. B. Mojsisch, Opera omnia, vol. 1. Schriften zur Intellekttheorie (Hamburg: Meiner, 1977), 3.2.3, p. 72, l. $40-$ p. 73, l. 64 .

59 Berthold of Moosburg, Expositio, 196F, p. 128, l. 171-177; p. 129, l. 223-p. 13o, l. 245; 210C, p. 249, l. 83-103; 210E, p. 252, l. 185-p. 253, l. 227. 
the perfection of man, which for Berthold is the ultimate goal of the whole Elementatio theologica and therefore also of his Expositio. After examining many of these citations, we can now answer our initial question about how Berthold uses the Bible. It is apparent that he does not merely use the Bible as superfluous decoration. Instead, his biblical citations fulfil various important functions depending on the context. In some places Berthold uses them as authorities or even as evidence on which a further thought is based. By this usage, Berthold shows the concordance of Proclean philosophy and Scriptural revelation. Several times this opens up a new meaning for the biblical passage itself. However, we also find in Berthold the integration of statements from Proclus into the coordinate system of revelation. His biblical quotations often contribute new points of view and contents that are not found in the text of Proclus. For example, the one God is presented as Father and as Lord Jesus Christ. Furthermore, the eschatological vision of God is conceived in personal categories as a face-to-face vision, that is, not only as a vision of cosmological structures, but above all as the vision of God's face. In the context of the passages in which Berthold quotes the Bible, it is also noticeable how often he brings up Christian concepts and contents such as in patria, fides, meritum, gratia, donum Dei, lumen gloriae and resurrectio. While citing the Bible, Berthold sometimes also refers to dogmatic concepts and doctrines.

Incidentally, the determining influence of Christian doctrine is even more evident in other passages in which there are no quotations from the Bible. Thus Berthold explains in the commentary on Proposition 106 that a certain theory applies even if the movement of heaven and time are not eternal and then adds: ut veritas est fidei Christianae. ${ }^{60}$ When Proclus explicitly denies in Proposition 28 that a producer and its product can be equal in their power, Berthold contradicts this in his commentary, speaking in detail about the Trinity, where there is precisely such equality. ${ }^{61}$ Without explicit reference to the faith, but in keeping with it, Berthold also rejects the Proclean ideas of the eternal descent and ascent of human souls ${ }^{62}$ and the transmigration of souls. ${ }^{63}$ In the commentary on Proposition 204, Berthold reaches a determination on the question of human animation with a quotation from Thomas Aquinas. ${ }^{64}$ Aquinas there argues for the creation of the soul at the very moment of its

\footnotetext{
6o Berthold of Moosburg, Expositio, 106B, p. 241, l. 34.

61 Berthold of Moosburg, Expositio, 28A, p. 173, l. 77-81; 28B, p. 174, l. 123-p. 175, l. 141; 28D, p. 176, l. 171-173.

62 Berthold of Moosburg, Expositio, 206F, p. 223, l. 262-268.

63 Berthold of Moosburg, Expositio, 199E, p. 16o, l. 300-p. 161, l. 321.

64 Unlike Dietrich, Berthold does not avoid naming Thomas Aquinas. This is probably due to the canonization of Thomas Aquinas in 1323. Accordingly, Berthold calls him Sanctus Thomas.
} 
infusion into the body and names traducianism and the pre-existence of the soul as condemned heresies. ${ }^{65}$ In addition, in the commentary on Proposition 154, Berthold gives a quotation from Dionysius that alludes to the sacrament of the Eucharist. 66

Taken together, this indicates that we cannot consider an equal coexistence of pagan wisdom and the Christian concept of revelation in Berthold's Expositio. Instead, Berthold establishes a synthesis of pagan and Christian wisdom. This synthesis is formed under the clear auspices of Christian doctrine. It is in this sense that the 73 Biblical citations in the Prologus should be understood, for they indicate from the very beginning the auspices under which everything else is to be found. Thus, far from being merely a literal commentary on a philosophical text, the Expositio is in fact a Christian interpretation of Proclean thought.

Finally, I would like to say something very briefly about the distinction between providentia naturalis and providentia voluntaria in Berthold's Expositio. It has often been claimed, for example by Kurt Flasch, that Berthold understood (Proclean) philosophy as an area of providentia naturalis and Christian theology as an area of providentia voluntaria. ${ }^{67}$ But this is inaccurate, because Berthold knows very well that Proclus in his Opuscula deals with providentia voluntaria, as the following text shows (important words in bold):

Ista sunt invisibilia Dei transitive accepta, de quibus in ista elementatione theologica subtilissime pertractatur, quantum pertinet ad providentiam naturalem. Sunt praeterea invisibilia Dei providentiae voluntariae, puta angeli, qui, ut dicit Proclus De malorum existentia 3 cap., sunt 'genus interpretativum deorum continuum existens dis'. ${ }^{68}$

65 Berthold of Moosburg, Expositio, 204A, p. 203, l. 100-116.

66 Berthold of Moosburg, Expositio, 154A, p. 159, l. 34-44.

67 Flasch, "Einleitung", p. xiv and p. xxxii. This assessment seems to be confirmed by the following lines in Berthold of Moosburg, Expositio, 5B, p. 116, 1. 104-112: Sed dices, quod Dionysius loquitur ut theologus, qui solum considerat processum rerum a Deo secundum ordinem providentiae voluntariae, et ideo aliter est de processu rerum a Deo secundum ordinem providentiae naturalis, ubi proceditur ab uno in multitudinem ordinate, de quo loquuntur philosophi theologizantes sive theologi philosophantes. Quare, ut videtur, adhuc manet eorum principium inconcussum, scilicet quod ab uno solo singulariter existenti non debeat procedere nisi unum, et idem eodem modo manens semper natum est facere idem. Igitur positio Peripateticorum videtur adhuc esse firma. However, it should be noted that Berthold is here presenting the objection (Sed dices) of an imaginary opponent, who supports the opinion of the Peripatetics (!). Moreover, the solution of this objection shows that the positio Platonicae philosophiae (p. 116, l. 130) falls into line with Dionysius.

68 Berthold of Moosburg, Expositio, Prol. 5-6, p. 13, l. 264-269 ("These are the invisible realities of God taken transitively, about which this Elementatio theologica deals with in a very subtle way, as far as it belongs to the providentia naturalis. There are also invisible 
Berthold also never claims in his Expositio that he only wants to talk about the area of providentia naturalis and not also about providentia voluntaria. Rather, in the prologue he merely excludes the angels, about whom Proclus also wrote in his Opuscula, as a topic for his Expositio. What Berthold really says is this (important words in bold):

Et quia totus iste liber tractat de rerum divinarum universitate secundum processum eius a summo bono et regressum in ipsum, et hoc secundum dispositionem et proprios modos earum inditos ipsis rebus divinis ab eo, quod est divinum principaliformiter sive secundum causam, et hoc secundum ordinem providentiae naturalis, non iam proprie voluntariae, iuxta distinctionem Augustini viII Super Genesim ad litteram, necesse est omnia convenire, de quibus hic tractatur, in una ratione subiecti, propter quam etiam ista philosophia est una scientia. ${ }^{69}$

Thus, according to Berthold, Proclus in his book Elementatio theologica deals only with the area of providentia naturalis. ${ }^{70}$ What is said in Proclus' book forms a part of philosophy and is therefore called "this philosophy" (ista philosophia) by Berthold. However, Berthold admits that even in the Elementatio theologica there are some hints and remarks on the area of providentia voluntaria (non iam proprie voluntaria). In accordance with the Elementatio theologica, Berthold wants to write in his own Commentary mainly about the area of providentia naturalis. In doing so, he very often and at important points brings

realities of God that belong to the providentia voluntaria, such as the angels who, as Proclus says in the third chapter of De malorum existentia, are a 'genus of interpreters of the gods, which is close to the gods'").

69 Berthold of Moosburg, Expositio, Expos. tit. I, p. 46, 1. 319-326 ("And since this whole book deals with the totality of the divine things according to the procession from the supreme good and the return to it, and this according to the disposition and the proper modes, which are given to these divine things by that which is Divine in the principal or causative way, and this according to the order of providentia naturalis, and not yet actually according to providentia voluntaria (according to the distinction of Augustine in the eighth book of the Literal Commentary on Genesis), therefore it is necessary that everything that is dealt with here falls under one subject, which is why this philosophy is also a single science."). Note that Berthold here deliberately inserted the words non iam proprie voluntariae into the text, which is mainly a quotation of Dietrich of Freiberg's De subiecto theologiae. Cf. Dietrich of Freiberg, De subiecto theologiae, ed. L. Sturlese, in Opera omnia, vol. 3. Schriften zur Naturphilosophie und Metaphysik, eds J.-D. Cavigioli et al. (Hamburg: Meiner, 1983), 3.5, p. 281, l. 69-77.

70 See also Berthold of Moosburg, Expositio, 120E, p. 100, 1. 303-304: Secundum primum actum providentiae est ordo naturalis causarum, qui in hoc volumine exprimitur [...]. 
in Christian teachings that extend or correct Proclus. However, Berthold also wants to say something about providentia voluntaria, about which Proclus in the Elementatio theologica, according to its purpose, is largely silent. For this purpose he draws frequently on the Proclean Opuscula and above all, however, on Christian doctrine. And again it is Christian doctrine - whether the Bible, the Fathers and other theologians, or dogma - that extends and corrects Proclus. Through this approach Berthold neither completely separates the areas of providentia naturalis and providentia voluntaria from each other, nor does he keep pagan philosophy and Christian theology apart. ${ }^{71}$ Like the Church Fathers and the earlier Scholastics before him, in both cases Berthold wants to integrate the two. The integration of pagan thinking into the Christian model of thought has important consequences for the Christian theology of revelation. As already with the Church Fathers, with Eriugena and Honorius or with Meister Eckhart, there are influences of pagan philosophy which are not unproblematic from the point of view of Christian theology. ${ }^{72}$ An example with Berthold is his Eriugenistic conception of the resurrected body.

In the end, Berthold's Expositio is, of course, not simply a work of Christian theology. The Expositio remains principally a philosophical work. Like the Church Fathers, however, Berthold's philosophy is illuminated by Christian theology. Thus, the Expositio is best understood as a Christian interpretation of the Elementatio theologica.

71 This is also the opinion of Alain de Libera. See A. de Libera, "Philosophie et théologie chez Albert le Grand et dans l'école dominicaine allemande", in A. Zimmermann (ed.), Die Kölner Universität im Mittelalter. Geistige Wurzeln und soziale Wirklichkeit (Berlin / New York: De Gruyter, 1989), p. 6o: “Chez Berthold, sapientia nostra ne s'oppose plus, comme chez Dietrich, à la scientia divina philosophorum. C'est que, de Dietrich à Berthold, les données du problème ont encore changé. La grande affaire de Berthold n'est plus de distinguer, voire d'opposer, théologie philosophique et théologie chrétienne, mais bien, et plus simplement, théologie et métaphysique, science divine et science de l'être en tant qu'être, platonisme et péripatétisme. D'un mot: Berthold reçoit la distinction des deux Providences: la naturelle et la volontaire; mais c'est ne plus pour y marquer la différence entre une philosophie, quelle qu'elle soit, et une théologie eschatologique. Chaque Providence a son porte-parole, et si l'on me passe l'expression, chacun d'eux parle la même langue: la Providence naturelle a Proclus, la Providence volontaire a le Pseudo-Denys; tous deux parlent le langage du suressentiel, du Bien suprême et de l'Un." De Libera is right that Berthold is not interested in an opposition and separation of philosophy and Christian theology. Yet Berthold does make a distinction between them. What is also wrong with De Libera's assessment is the clear assignment of providentia naturalis to Proclus and of providentia voluntaria to Dionysius. 


\section{Appendix}

\section{Legend}

The first and second columns indicate the location and scriptural source of Berthold's biblical citations and allusions. In many cases, Berthold explicitly indicates that he is drawing on a scriptural source, for instance by writing Ad Hebr. 11, illud Mosis, Audi Apostolum, Quod autem Scriptura dicit, sicut ipsa [sapientia] dicit, etc. An asterisk at the end of the first column indicates citations or allusions where Berthold does not explicitly acknowledge that he is using a biblical text.

If the third column contains the name of an author, the citation or allusion was already found in the text that Berthold has taken over from that author. When there is no such name, the citation or allusion is introduced by Berthold himself.

The fourth column indicates the specific way in which Berthold makes use of the Bible.

The category "exact" means that Berthold quotes the biblical passage in its exact wording or with very minor changes (e.g. a slight change in the word order, insertion of words like enim, or a modification of the grammatical person of the verb).

The category "cf." (which the editors of Berthold also use in their footnotes) stands for all biblical passages that are quoted with major changes (such as omission of words, significant change of word order, insertion of other words). E.g. Sapientia 9:15: corpus quod corrumpitur adgravat animam (original) vs. corpus corruptibile, quod aggravat animam (see below A., nr. 6).

The category "allusion" includes all passages in which one can no longer speak of a quotation in the strict sense, since Berthold (or the author he uses) significantly adapts the text of the Bible or mentions only a few words that are characteristic of the biblical passage. A small subset of these "allusions" is formed by "vague allusions", in which the identified biblical passage is hardly recognizable. Both types of "allusions" are classified in the footnotes of the critical edition as "cf."

The last category is "references". Here Berthold only refers to a biblical passage without quoting it.
A. Berthold of Moosburg 1984, vol. vi,1, Expositio. Prologus. Propositiones 1-13
1. Prol. $1(5,2-4)$
Ad Romanos 1:19
exact
2. Prol. $1(5,7-8)$
Ad Romanos 1:20
cf.
3. Prol. 1 (6,39f.)
Ad Romanos 1:19
exact
4. Prol. $1(6,43$ f. $)$
Sapientia 13:1-4
allusion
5. Prol. $1(6,44 f$.)
Sapientia 13:5
exact
6. Prol. $2(7,56)^{*}$
Sapientia 9:15
Augustinus
allusion
7. Prol. $2(7,68 \mathrm{f}$.)*
Proverbia 25:27
exact
8. Prol. $3(7,8 \circ-82)$
Ad Timotheum I 1:17
exact 
9. Prol. $3(8,90)$

10. Prol. $3(8,115)$

11. Prol. $4(12,218) *$

12. Prol. $4(12,219)^{*}$

13. Prol. $4(12,220)^{*}$

14. Prol. $4(12,221-223)$

15. Prol. $4(12,243$ f.)*

16. Prol. $9(14,308)$ *

17. Prol. 9 (14,309)

18. Prol. 9 (14,309)

19. Prol. 9 (14,311f.)*

2o. Prol. $9(14,312)$

21. Prol. 9 (15,315)

22. Prol. $9(15,341)$ *

23. Prol. $9(15,341 f$.)*

24. Prol. $10(16,349 f \text {. })^{*}$

25. Prol. $10(16,355)$ *

26. Prol. $10(16,355$ f.)*

27. Prol. 10 (16,36of.)*

28. Prol. $10(16,362)^{*}$

29. Prol. $10(17,386)^{*}$

30. Prol. $10(17,395)$ *

31. Prol. $10(17,396)^{*}$

32. Prol. $10(17,397 \mathrm{f} .)^{*}$

33. Prol. $11(18,420)$ *

34. Prol. 11 (18,421f.)

35. Prol. $11(18,428)$

36. Prol. $11(18,432)^{*}$

37. Prol. $11(18,434)^{*}$

38. Prol. $11(18,435)^{*}$

39. Prol. $11(18,437 \mathrm{f} .)^{*}$

40. Prol. $11(19,453)$ *

41. Prol. 11 (19,46o)

42. Prol. 11 (19,462f.)

43. Prol. 11 (19,472f.)

44. Prol. $11(19,473)$ *

45. Prol. 11 (20,11f.)*

46. Prol. 12 (20,501f.)*
Ad Colosenses 1:15

exact

Ad Hebraeos 11:13

Psalmus 94:3

Psalmus 96:9

Psalmus 49:1

Ad Corinthios I 8:5-6

Psalmus 49:1

Psalmus 148:4

Psalmus 148:5

Psalmus 32:9

Ad Timotheum 6:16

Psalmus 17:12

Genesis 1:2

Sapientia 8:1

Sapientia 11:21

Ad Timotheum 6:15

Psalmus 94:3

Psalmus 96:9

Psalmus 144:13

Psalmus 148:6

Ecclesiasticus 42:16

Psalmus 144:5

Isaias 12:5

Daniel 3:56

Proverbia 9:1

Baruch 3:24-25

Psalmus 25:8

Ad Timotheum I 6:16

Daniel 3:54

Psalmus 144:3

Proverbia 9:1

Ad Psalmos 103:5

Ecclesiasticus 24:7

Iob 26:1 1

Psalmus 47:4

Psalmus 86:3

Ad Ephesios 2:21-22

Genesis 15:5 exact

exact

exact

exact

exact

exact

exact

exact

exact

cf.

cf.

Honorius

exact

cf.

cf.

exact

exact $^{73}$

cf.

cf.

cf.

exact

cf.

exact

exact

exact

exact

exact

cf.

exact

cf.

exact

cf.

exact

exact

exact

exact

allusion

cf.

73 This citation is mentioned in the footnotes, but not in the Index. 
47. Prol. $12(20,502)^{*}$

48. Prol. $12(21,516 f$ f.

49. Prol. 13 (22,559f.)

50. Prol. $13(22,561)^{*}$

51. Prol. $13(22,561)$ *

52. Prol. $13(22,564-566)$

53. Prol. $13(22,566)$

54. Prol. 17 (26,683f.)*

55. Prol. 18 (27,735f.)*

56. Prol. $19(29,781-783)$

57. Prol. 19 (29,783)

58. Prol. 19 (29,783f.)

59. Prol. 19 (29,800-802)

6o. Prol. 19 (29,802f.)

61. Prol. 19 (30,804f.)

62. Prol. 19 (30,8०5f.)

63. Prol. 19 (30,813f.)

64. Prol. $19(30,822)^{*}$

65. Prol. $19(31,859)^{*}$

66. Prol. $19(31,868 f$ f $)$

67. Prol. 19 (31,87of.)*

68. Prol. $19(32,877$ f. $)$

69. Prol. 20 (33,9ogf.)

70. Prol. 20 (33,939-34,943)

71. Prol. $20(34,944)$ *

72. Prol. $21(34,970)$ *

73. Prol. 21 (34,97of.)*

74. Expos. tit. E $(411,63$ f.)

75. Expos. tit. L $(51,489 f .)^{*}$

76. Prop. 3 B $(94,77$ f.)*

77. Prop. $12 \mathrm{E}(2 \mathrm{O} 2,173 \mathrm{f} \text { ) })^{*}$

78. Prop. 12E $(202,191)^{*}$
Ecclesiasticus 43:10

Genesis 1:27

Psalmus 73:16

Sapientia 7:21

Sapientia 7:23

Psalmus 91:6-7

Psalmus 91:5

Ad Philippenses 4:7

Genesis 1:27

Ecclesiasticus 43:20

Sapientia 7:26

Ad Hebraeos 1:3

Psalmus 95:6

Psalmus 103:1-2

Psalmus 96:6

Psalmus 104:1-2

Ieremias 32:23

Psalmus 49:11

Epistula Ioannis I 1:5

Psalmus 4:7

Ad Corinthios I 13:12

Genesis 1:27

Ad Romanos 1:19-20

Psalmus 41:2-5

Cantica 2:9

Ad Hebraeos 1:3

Evang. sec. Ioannem 1:9

Ecclesiasticus 1:5

Ad Timotheum I 2:5

Ad Romanos 11:36

Psalmus 71:17

Epistula Iacobi 1:17 cf.

cf.

cf.

cf.

exact

exact

exact

cf.

cf.

exact

cf.

cf.

exact

exact

exact

exact

exact

exact

exact $^{74}$

exact

cf.

cf.

reference

exact

allusion

allusion

exact

exact

cf.

cf.

cf.

exact

74 Here the footnote in the text and the Index mistakenly refer to the Gospel of John instead of the First Epistle of John. 
B. Berthold of Moosburg 1986, vol. VI,2, Expositio. Propositiones 14-34 ${ }^{75}$

1. Prop. ${ }_{15} \mathrm{~F}(22,262) * \quad$ Ad Romanos 1:25

cf.

2. Prop. $16 \mathrm{D}(27,111 \mathrm{f} \text {. })^{*}$ Ad Romanos 1:25

cf.

3. Prop. $18 \mathrm{~B}(46,98)$

Genesis 1:1

Honorius

exact

4. Prop. $18 \mathrm{C}(50,244)^{*}$

Epistula Iacobi 1:17

Dionysius

exact

5. Prop. $26 \mathrm{H}\left(158,177^{\mathrm{f}}\right)^{*} \quad$ Sapientia 8:1

6. Prop. $30 \mathrm{D}(196,200) \quad$ Evang. sec. Ioannem

Ioannes Scotus

cf.

7. Prop. 32D (209,116)

Epistula Ioannis I 3:1-2

exact

8. Prop. $32 \mathrm{~F}(212,223)^{*}$

Sapientia 11:21

reference

exact

C. Berthold of Moosburg 2001, vol. VI,3, Expositio. Propositiones 35-65

1. Prop. $6 \mathrm{oD}(173,98 \mathrm{f}$.)* Psalmus $94: 3$

exact

D. Berthold of Moosburg 2003, vol. VI,4, Expositio. Propositiones 66-107

1. Prop. $69 \mathrm{~F}(23,122)^{*} \quad$ Ad Corinthios I 8:6

Dionysius

exact

2. Prop. $69 \mathrm{~F}(23,123)^{*}$

Ad Corinthios I 12:11

Dionysius

exact $^{76}$

3. Prop. 10oI $(208,171)^{*}$

Psalmus 94:3

exact

E. Berthold of Moosburg 2011, vol. VI,5, Expositio. Propositiones 108-135

1. Prop. 114A $(41,28 f$. $) * \quad$ Psalmus 94:3

Thomas of York exact

2. Prop. $115 \mathrm{E}(54,144)^{*} \quad$ Deuteronomium 32:4

cf.

3. Prop. 115E $(54,146 f \text {. })^{*}$ Psalmus 17:12

exact

4. Prop. $115 \mathrm{E}(54,147)^{*}$

Ad Timotheum I 6:16

exact

5. Prop. ${ }_{11} \mathrm{~F}(72,163)$

Sapientia 11:21

Augustinus

cf.

6. Prop. ${ }_{117} \mathrm{~F}(73,174 \mathrm{f}$ )

Sapientia 11:21

Augustinus

exact

7. Prop. 118A $(76,42)$

Evang. sec. Ioannem 1:3-4

Augustinus

exact

8. Prop. $119 \mathrm{C}(84,36)$ * Ad Romanos 11:36

cf.

9. Prop. $120 \mathrm{OD}(98,262 \mathrm{f}$.)*

Ad Corinthios I 12:1 1

Honorius

cf.

10. Prop. 122B $(116,69 f$.)* Sapientia 8:1

11. Prop. 123B $(126,55)^{*} \quad$ Ad Romanos 11:36

Bonaventura

exact

12. Prop. $123 \mathrm{~K}(133,278)$ *

Sapientia 11:21

exact

13. Prop. $123 \mathrm{~K}(133,283)$

Evang. sec. Ioannem 1:3

exact

vague

allusion

14. Prop. 123L $(134,312) \quad$ Ad Romanos 9:5

Dionysius

exact

15. Prop. 123L $(135,339)^{*}$ Psalmus 17:12

exact

75 I could not identify the reference for Sapientia 8:1 indicated in the critical edition for Prop. $32 \mathrm{~F}(212,222)$.

76 Here I omit the two parallel references (Ad Ephesios 4:6 and Ad Ephesios 4:4) indicated by the editor for Prop. $69 \mathrm{~F}(23,122)$ and Prop. $69 \mathrm{~F}(23,123)$. 
16. Prop. 126B (154,20f.)

17. Prop. 126B $(155,44-46)$ *

18. Prop. 126B $(156,77)$ *

19. Prop. 126B $(157,88)$

20. Prop. 128A (167,31f.)*

21. Prop. 128B $(168,79)$ *

22. Prop. 129A $(176,114)^{*}$

23. Prop. 129A $(177,130)^{*}$

24. Prop. 129B $(179,189)$ *

25. Prop. 129B $(179,191)^{*}$

26. Prop. 129B $(179,194)$ *

27. Prop. 129B $(179,197)$ *

28. Prop. ${ }_{131} \mathrm{~A}(191,40)^{*}$

29. Prop. 131B (191,52f.)

3o. Prop. 131B (191,55-192,56)

31. Prop. 131B $(192,56)$

32. Prop. 131B (192,56f.)

33. Prop. 132B $(201,30)^{*}$

34. Prop. $132 \mathrm{C}(201,41)^{*}$

35. Prop. $133 \mathrm{H}(211,164)^{*}$

36. Prop. $133 \mathrm{H}(212,183)^{*}$
Ad Romanos 11:36

Epistula Iacobi 1:17

Genesis 1:2

Genesis 1:2

Psalmus 94:3

Sapientia 11:21

Evang. sec. Lucam 16:22

Ad Corinthios I 15:44

Ad Corinthios I 6:16

Psalmus 35:9

Ad Corinthios I 15:28

Ad Ephesios 3:19

Ad Romanos 1:19

Evang. sec. Ioannem 1:16

Evang. sec. Ioannem 1:16

Evang. sec. Ioannem 1:16

Ad Philippenses 2:6-11

Ad Romanos 13:1

Sapientia 11:21

Ad Romanos 11:36

Deuteronomium 32:4 exact

exact

cf.

Honorius exact

Honorius exact

cf.

allusion

cf.

Freiberg

Bernardus cf.

Bernardus cf.

Bernardus cf.

exact

Thomas of exact

York

Thomas of cf

York/August.

Thomas of exact

York/August.

Thomas of allusion

York/August.

Thomas of exact

York/August.

exact

cf. 77

cf.

exact

F. Berthold of Moosburg 2007, vol. vi,6, Expositio. Propositiones 136-159

1. Prop. $136 \mathrm{E}(9,178)^{*}$

Ad Romanos 11:36

cf.

2. Prop. $140 \mathrm{C}(39,63)^{*}$

Sapientia 8:1

exact

3. Prop. $140 \mathrm{OD}(40,81 \mathrm{f} .)^{*}$

Epistula Iacobi 1:17

Honorius

exact

4. Prop. $140 \mathrm{OD}(40,88)^{*}$

Ad Romanos 11:36

Honorius

cf.

Ad Corinthios I 15:28

Honorius

exact

Ad Corinthios I 15:28

Honorius

exact $^{78}$

Genesis 2:15

exact

Sapientia 8:1

exact

Evang. sec. Ioannem 1:5 Honorius

cf.

77 Here the footnote in the text and the Index refer mistakenly to Sapientia 8:20.

78 The citations are indicated twice in the footnotes, but only once in the Index for page 42. 
10. Prop. $143 \mathrm{~K}(68,291)^{*} \quad$ Epistula Ioannis I 1:5

exact

11. Prop. 143 L (70,351f.)* Sapientia $7: 26$

exact

12. Prop. $143 \mathrm{M}(70,357)^{*}$

Evang. sec. Lucam 1:79

cf.

13. Prop. $144 \mathrm{~B}(75,25)^{*}$

Sapientia 8:1

14. Prop. 144B (75,27f.)

Sapientia 11:21

exact

15. Prop. $144 \mathrm{~B}(76,32)$

Sapientia 11:21

Ulrich of

exact

Strassburg

16. Prop. $144 \mathrm{~B}(76,40)^{*}$

Ad Colosenses 1:16

17. Prop. $144 \mathrm{~B}(76,41)$

Ad Colosenses 1:16

18. Prop. 144B $(76,49)$

Sapientia 7:17

Glossa ord.

cf.

Glossa ord.

exact

Ulrich of

exact

Strassburg

19. Prop. $144 \mathrm{~B}\left(76,5^{2}\right) \quad$ Sapientia $8: 1$

Ulrich of

exact

Strassburg

20. Prop. $144 \mathrm{C}(77,76)^{*}$

Sapientia 11:21

21. Prop. 146I (96,204)*

Epistula Ioannis I 3:1-2

Thomas of

York

exact

22. Prop. ${ }_{147} \mathrm{~A}(100,16)^{*} \quad$ Isaias 61:10

23. Prop. $147^{B}(102,56)^{*} \quad$ Ad Romanos 11:36

Dionysius

Damascenus

Damascenus

cf.

24. Prop. 151 A $(133,38)^{*}$

Ad Hebraeos 1:3

25. Prop. $151 \mathrm{~A}(133,39)^{*}$

Ad Corinthios I 1:24

Damascenus

Dionysius

Dionysius

28. Prop. $151 \mathrm{~A}(135,100)^{*}$ Epistula Iacobi 1:17

29. Prop. ${ }_{151} \mathrm{~B}(136,132)^{*} \quad$ Ad Romanos 11:36

3o. Prop. 151B $(136,137)^{*}$ Ad Ephesios 3:14-15

31. Prop. 152B (140,27f.) Ad Ephesios 3:14-15

32. Prop. $156 \mathrm{~B}(171,69) \quad$ Epistula Ioannis I 1:5

Damascenus

vague

allusion

allusion

33. Prop. 159I (199,311) Sapientia 11:21

exact

exact

cf.

exact

exact

allusion

cf.

exact

exact

cf.

cf.

G. Berthold of Moosburg 2003, vol. vi,7, Expositio. Propositiones 16o-183

1. Prop. $162 \mathrm{E}(20,142)^{*}$ Psalmus 17:12

exact

2. Prop. $162 \mathrm{E}(20,151 \mathrm{f} \text {. })^{*}$ Ad Timotheum I 6:16 Dionysius

cf.

3. Prop. $177 \mathrm{D}(177,133$ f.)* Isaias 6:3

cf.

4. Prop. 178E $(196,261)^{*}$ Ad Romanos 11:36

cf.

5. Prop. 179B $(205,178)^{*}$ Sapientia 11:21

cf.

H. Berthold of Moosburg 2014, vol. vi,8, Expositio. Propositiones 184-211
1. Prop. $185 \mathrm{I}\left(25,35^{8}\right)$
Ad Thessalonicenses I
Dionysius
exact 4:17
2. Prop. $185 \mathrm{I}(25,361 \mathrm{f}$.)
Evang. sec Matthaeum
Dionysius
allusion 


\begin{tabular}{|c|c|c|c|}
\hline 3. Prop. $185 \mathrm{I}(25,364 \mathrm{f})$. & Evang. sec. Lucam 20:36 & Dionysius & cf. \\
\hline 4. Prop. 190A $(77,37)^{*}$ & Sapientia 11:21 & Augustinus & cf. \\
\hline 5. Prop. 19oA $(77,51 \mathrm{f} .)^{*}$ & Sapientia 8:1 & Thomas of York & cf. \\
\hline 6. Prop. 19oA $(77,53)$ & Ecclesiastes 7:26 & Thomas of York & cf. \\
\hline 7. Prop. 196F $(128,174)^{*}$ & Ad Romanos 5:12 & Honorius & cf. \\
\hline 8. Prop. $196 \mathrm{~F}(128,183)^{*}$ & Genesis $2: 7$ & Honorius & cf. \\
\hline 9. Prop. 196F $(128,186)$ & Genesis 2:7 & Honorius & cf. \\
\hline 10. Prop. 196F $(128,193)^{*}$ & Ad Corinthios I $15: 53$ & Honorius & cf. \\
\hline 11. Prop. 196F $(128,194)$ & Ad Corinthios I 15:44 & Honorius & cf. \\
\hline 12. Prop. 196F (129,207) & Genesis $1: 26$ & Gregorius Nyss. & exact \\
\hline 13. Prop. 196F $(130,243)^{*}$ & Ad Philippenses 2:7 & Honorius & cf. \\
\hline 14. Prop. 196F $(130,244)^{*}$ & Ad Corinthios 15:54 & Honorius & cf. \\
\hline \multirow[t]{2}{*}{ 15. Prop. 202B (185,131f.) } & Evang. sec Matthaeum & Dionysius & allusion \\
\hline & $17: 1$ & & \\
\hline 16. Prop. $202 \mathrm{~B}(185,135$ f. $)$ & Evang. sec. Lucam 20:36 & Dionysius & cf. \\
\hline 17. Prop. $202 \mathrm{~F}\left(188,225^{f} .\right)^{*}$ & Psalmus 17:12 & & cf. \\
\hline 18. Prop. $202 \mathrm{~F}(188,226)^{*}$ & Psalmus 94:3 & & exact \\
\hline 19. Prop. $202 \mathrm{~F}(188,230)^{*}$ & Ad Corinthios I 13:12 & & cf. \\
\hline 20. Prop. $203 \mathrm{~A}(190,22)^{*}$ & Isaias 12:4 & Avencebrol & cf. \\
\hline 21. Prop. 204A $(202,73)$ & Genesis $2: 2^{79}$ & Nemesius Emes. & cf. \\
\hline 22. Prop. 204A $(202,74)$ & Evang. sec. Ioannem 5:17 & Nemesius Emes. & exact \\
\hline \multirow[t]{2}{*}{ 23. Prop. 208A (232,27f. $)^{*}$} & Ad Corinthios I 15:44 & Dietrich of & cf. \\
\hline & & Freiberg & \\
\hline 24. Prop. 21 oC (249, 87f. $)$ & Ad Romanos 8:21 & Honorius & exact \\
\hline 25. Prop. 21oC (249,88f. $)$ & Ad Corinthios II 5:1 & Honorius & exact \\
\hline 26. Prop. $210 \mathrm{C}(249,94)$ & Ad Corinthios II 4:2 & Honorius & exact \\
\hline 27. Prop. $210 \mathrm{C}(249,99 f)$. & Ad Corinthios I 2:9 & Honorius & exact \\
\hline 28. Prop. $210 \mathrm{OE}\left(25^{2,192 \mathrm{f} .}\right)$ & $\begin{array}{l}\text { Evang. sec. Marcum 12:25 } \\
\text { par. }^{80}\end{array}$ & Honorius & exact \\
\hline 29. Prop. $210 \mathrm{M}(255,320)^{*}$ & Ad Romanos 8:19 & Honorius & cf. \\
\hline 30. Prop. 211 A $(259,43)^{*}$ & Ad Romanos 11:36 & & cf. \\
\hline
\end{tabular}

79 Here I omit the two parallel references from the book Exodus indicated by the editor.

8o Here I omit the two parallel references from the Synoptic Gospels indicated by the editor. 


\section{Bibliography}

\section{Primary Sources}

Berthold of Moosburg, Expositio super Elementationem theologicam Procli. Prologus. Propositiones 1-13, eds M.R. Pagnoni-Sturlese, L. Sturlese, Hamburg, Meiner, 1984.

Berthold of Moosburg, Expositio super Elementationem theologicam Procli. Propositiones 14-34, eds L. Sturlese, M.R. Pagnoni-Sturlese, B. Mojsisch, Hamburg, Meiner, 1986.

Berthold of Moosburg, Expositio super Elementationem theologicam Procli.Propositiones 35-65, ed. A. Sannino, Hamburg, Meiner, 2001.

Berthold of Moosburg, Expositio super Elementationem theologicam Procli.Propositiones 66-107, ed. I. Zavattero, Hamburg, Meiner, 2003.

Berthold of Moosburg, Expositio super Elementationem theologicam Procli.Propositiones 108-135, ed. F. Retucci, Hamburg, Meiner, 2011.

Berthold of Moosburg, Expositio super Elementationem theologicam Procli.Propositiones 136-159, ed. F. Retucci, Hamburg, Meiner, 2007.

Berthold of Moosburg, Expositio super Elementationem theologicam Procli.Propositiones 160-183, eds U.R. Jeck, I.J. Tautz, Hamburg, Meiner, 2003.

Berthold of Moosburg, Expositio super Elementationem theologicam Procli.Propositiones 184-211, ed. L. Sturlese, Hamburg, Meiner, 2014.

Dietrich of Freiberg, De subiecto theologiae, ed. L. Sturlese, in Opera omnia, vol. 3. Schriften zur Naturphilosophie und Metaphysik, eds J.-D. Cavigioli et al., Hamburg, Meiner, 1983, p. 279-282.

Dietrich of Freiberg, De visione beatifica, ed. B. Mojsisch, in Opera omnia, vol. 1. Schriften zur Intellekttheorie, ed. B. Mojsisch, Hamburg, Meiner, 1977, p. 7-124.

Dionysius ps.-Areopagita, Dionysiaca, ed. Ph. Chevallier, 2 vols, Bruges, Desclée de Brouwer, 1937.

\section{Secondary Sources}

Cremascoli, G., Leonardi, C. (eds), La Bibbia nel Medio Evo, Bologna, EDB, 1996.

Dahan, G., L'exégèse chrétienne de la Bible en Occident médiéval. XII ${ }^{e}-X I V^{e}$ siècle, Paris, Cerf, 1999.

Dahan, G., Lire la Bible au Moyen Âge. Essais d'herméneutique médiévale, Genève, Librairie Droz, 2009.

Eckert, W.P., Berthold von Moosburg O.P. und sein Kommentar zur Elementatio Theologica des Proklos, PhD diss., Ludwig-Maximilians-Universität München, 1956.

Eckert, W.P., "Berthold von Moosburg O.P. Ein Vertreter der Einheitsmetaphysik im Spätmittelalter", in Philosophisches Jahrbuch 65(1957), p. 120-133.

Flasch, K., "Einleitung", in Berthold of Moosburg, Expositio super Elementationem theologicam Procli. Prologus. Propositiones 1-13, eds M.R. Pagnoni-Sturlese, L. Sturlese, Hamburg, Meiner, 1984, p. xi-xxxviii. 
Libera, A. de, "Philosophie et théologie chez Albert le Grand et dans l'école dominicaine allemande", in A. Zimmermann (ed.), Die Kölner Universität im Mittelalter. Geistige Wurzeln und soziale Wirklichkeit, Berlin / New York, De Gruyter, 1989, p. 49-67.

Lubac, H. de, Exégèse médiévale. Les quatre sens de l'Écriture, 4 vols, Paris, Aubier, 1959-1964.

Ludueña, E., La recepción de Eriúgena en Bertoldo de Moosburg. Un aporte sobre la Escuela de Colonia, Saarbrücken, Publicia, 2013.

Ludueña, E., "Eriúgena en el siglo XIV. Su presencia en la Expositio de Bertoldo de Moosburg", in Scintilla 10(2013), p. 99-154.

Massa, E., "La deificazione nel commento di Bertoldo di Moosburg a Proclo, Elementatio theologica, 129. Edizione del testo e prime analisi", in R. Lievens, E. Van Mingroot, W. Verbeke (eds), Pascua Mediaevalia. Studies voor Prof. Dr. J.M. De Smet, Leuven, Leuven University Press, 1983, p. 545-6o4.

Retucci, F., "Einleitung", in Berthold of Moosburg, Expositio super Elementationem theologicam Procli. Propositiones 108-135, ed. F. Retucci, Hamburg, Meiner, 2011, p. ix-Xviii.

Smalley, B., The Study of the Bible in the Middle Ages, Oxford, Blackwell, 1984.

Sturlese, L., Homo divinus. Philosophische Projekte in Deutschland zwischen Meister Eckhart und Heinrich Seuse, Stuttgart, Kohlhammer, 2007.

Suchla, B.R., Dionysius Areopagita. Leben - Werk - Wirkung, Freiburg, Herder, 2008. 